\title{
Geocaching in the Czech Republic and India with a Focus on Selected Aspects - Comparative Study
}

\author{
Miloslava ČERNÁ, Libuše SVOBODOVÁ \\ University of Hradec Králové, Hradec Králové, Czech Republic \\ \{miloslava.cerna, libuse.svobodova\}@uhk.cz
}

\begin{abstract}
The article deals with a multidisciplinary phenomenon called geocaching. Various aspects of geocaching form the core of this paper. The aim of the paper is to map current situation in geocaching and location of caches in the Czech Republic and India, to be precise in the city of Hradec Králové, Prague and New Delhi. The first sub-goal is to compare occurrence of various kinds of caches in two cities and give a real illustrative example of geocaching activity. The other sub-goal is to compare both countries according to the Networked Readiness Index (NRI). The findings are accompanied by tables and figures. In spite of the fact that India is so many times larger than the Czech Republic the occurrence of caches is small. In Hradec Králové with less than 100,000 people there are more caches than in the whole India. India still hasn't found the potential of geocaching for the promotion of sustainable tourism and development of the economics.
\end{abstract}

Keywords: Czech Republic, Geocaching, India, Network Readiness Index.

\section{Introduction}

Geocaching is a global phenomenon. This multidisciplinary issue encompasses many areas that mingle and influence one another. Geocaching as a hobby or leisure activity is unambiguously a game or sport characterized by a hunt for treasure; that is the first what comes into mind when people hear this word. But Geocaching is currently often presented as a tool with a powerful potential to promote Tourism and Cultural Heritage. Another perspective, which Geocaching is being approached to, is the economic perspective. There is general support of Information and communication technologies and computer literacy in the state policies so that these countries could succeed in the digital world. This location-based treasure hunt game, which is based on network cooperation and digital competences where players use Global Position System (GPS), corresponds to state policies. The economic, social, heritage and education aspects of geocaching forms the core of this paper. 


\section{Methodology and goal of the paper}

The paper deals with geocaching in two distant worlds, in two different economies, in two different cultures. The aim of the paper is to map the current situation in geocaching in the Czech Republic and India, to be precise in the city of Hradec Králové, Prague and New Delhi. One sub-goal is to compare occurrence of various kinds of caches in two cities and give a real illustrative example of geocaching activity. The other sub-goal is to compare both countries according to the Networked Readiness Index (NRI). NRI which was developed and introduced by the World Economic Forum to measure how countries use information and communication technologies and how they increase their competitiveness.

The article is based on primary and secondary sources. The secondary sources provide information about network readiness index, professional literature and information collected from professional press, web sites, discussions and previous participation at professional seminars and conferences related to the chosen subject. Then it was necessary to select, classify and update accessible relevant information from the numerous published materials that provide the basic knowledge about the selected topic.

\section{$3 \quad$ Literature review}

The Czech Republic is a geocaching superpower. India is just entering the world of Geocaching. India is currently a quickly developing country especially in technologies. In 2017, the Indian economy was the world's sixth largest by nominal GDP. [11]

Both countries can boast with marvelous Cultural and Natural Heritage with a great amount of unique UNESCO sites. The Czech Republic covers only an area of 78,866 square kilometers and has about 10.6 million inhabitants but can offer Twelve Czech wonders of the world and astonishing Intangible cultural heritage, e.g. Falconry, Kings' ride or Puppetry, see more [23]. As for India, it is the seventh largest country covering the area of $3,287,263$ square kilometers with population over 1.2 billion people. There are 28 cultural sites, seven natural sites and in 2016 one mixed site Khangchendzonga National Park was added to the UNESCO World Heritage list, see more [21].

Literature review brings selected studies dealing with Geocaching and its relevant aspects in three domineering areas: tourism, education and economy. Key terms aren't explained separately; they are mostly presented within a frame of the literature review. The outburst of Geocaching is connected with the historical moment when private citizens were in May 2000 given access to more accurate signals, allowing more precise locations to be found. [5]

The beginnings of Geocaching is as adventurous as the game itself. Just one day after the Department of Defence of the United States enabled its citizens to use Global Positioning System (GPS) satellites without any limitations; the first container with a 
logbook were placed in Oregon and GPS coordinates of the first cache were posted to an online satellite newsgroup. [1]

When two key terms "Geocaching and Economy" were placed into the search engine in two technical scientific literature databases Scopus and Web of Science only one article was found. In both databases it was the same article dealing with hybrid economies of collaborative networks. [17] The authors discuss hybrid economies within the context of market - based exchange and sharing. They apply and develop performativity theory in this newly established consumer-producer collaborative consumption and production engagement. [17]

The role of the 'Performativity' is currently analysed topic in Economics, see [13]. Healy [4] in his paper 'Performativity of Networks' explains the issue of methods, which are these days applied in the Economy and Finance, and points to the autonomy of the field and the very different origins of the methods used.

The first article on this topic was already published in Scopus in 2002. In case just one key word - 'Geocaching' is given into the search engine, e.g. in the Scopus database, 138 academic articles are generated (to 10.12.2017). In Web of Knowledge there are 63 articles, on Science Direct 86, Springer Link 320 and Google Scholar with 7390 articles is from selected databases the biggest one.

The following table 1 illustrates the published materials in chronological order in selected databases. Geocaching expression was searched in Scopus in the following areas, title, abstract and keywords, in WoS it was searched in a topic area, in Science Direct in keywords section, in Springer Link in results and in Scholar Google is the free search field box.

Table 1. Geocaching and databases [3, 18, 18, 20, 25]

\begin{tabular}{lccccc}
\hline Database & Scopus & WoS & Science Direct & $\begin{array}{c}\text { Springer } \\
\text { Link }\end{array}$ & $\begin{array}{c}\text { Scholar } \\
\text { Google }\end{array}$ \\
\hline 2002 & 1 & 0 & 0 & 0 & 23 \\
2003 & 2 & 0 & 0 & 0 & 31 \\
2004 & 0 & 0 & 2 & 10 & 72 \\
2005 & 2 & 1 & 1 & 0 & 94 \\
2006 & 2 & 1 & 0 & 7 & 120 \\
2007 & 4 & 0 & 0 & 8 & 188 \\
2008 & 7 & 2 & 0 & 9 & 244 \\
2009 & 6 & 1 & 8 & 11 & 356 \\
2010 & 10 & 8 & 5 & 26 & 445 \\
2011 & 7 & 3 & 6 & 21 & 645 \\
2012 & 14 & 6 & 8 & 28 & 736 \\
2013 & 17 & 7 & 8 & 27 & 846 \\
2014 & 14 & 4 & 8 & 38 & 787 \\
2015 & 13 & 9 & 11 & 39 & 811 \\
2016 & 21 & 14 & 10 & 36 & 779 \\
2017 & 17 & 7 & 17 & 47 & 603 \\
2018 & 1 & 0 & 2 & 13 & 15 \\
Total & 138 & 63 & 86 & 320 & 7390 \\
\hline
\end{tabular}


The following area where Geocaching plays worthy role is the development of regions. Geocaching is a proven tool which is being used in the promotion of the Cultural heritage and its potential is still waiting to be fully revealed.

One of the first papers highlighting the potential of Geocaching in promotion of tourism and cultural heritage goes back to the 2009. [1] "Geocaching can provide Cultural Heritage organizations, which often have limited budgets and lack technical staff, with a method to:

- increase revenue and

- and provide value added services with minimal investment or technical training." [1]

Craigh [1] discusses the unique characteristics of technology driven game where virtual world of virtual community mingles with a physical place in search of real world cache. Not only positives are connected with the Geocaching game. As this global game is spreading, also pitfalls start to occur. One of the latest topics in Geocaching is the environmental issue. Hödl and Pröbstl-Haider [6] discuss the potential threat to the protected areas which are affected by the kind, number and difficulty of caches which are scattered in the Austrian national parks.

Nature conservation theme together with positives and negatives of Geocaching are discussed in the first paper on Geocaching in the Czech Republic which was published in 2010 under a proud title Czechia - the geocaching power [16].

Last topic in the literature review on Geocaching deals with implications of geocaching for social interactions of people and for education. Finish author Ihamäki explores this game in detail especially in the field of Education and Tourism. [7-9]

People, technology and outdoor life get connected in this game, moreover the boundaries between game and non-game get broken. [7]

Ihamäki, P. [9] in her thesis User Experience of Geocaching and Its Application to Tourism and Education refers to the Australian author Webb [24] as to the first researcher who wrote about geocaching game about Recreational Geocaching Sport presenting it beside other characteristics as and innovating teaching approach for introduction to GPS.

\section{$4 \quad$ Findings}

The first part of findings relates to the occurrence and comparison of various kinds of caches in New Delhi and Hradec Kralove.

\subsection{Geocaching in the Czech Republic and in the India}

Globally, based on the Geocaching.com webpage, geocaching has been played about 200 countries and there are more than 12 million registered geocachers worldwide [2]. Amount of caches is a distinctive indicator of Geocaching popularity in individual countries. In December 2017 there were there were 56, 073 active caches in the Czech Republic but in the whole India there were only 261 caches which is even fewer 
caches than in the Czech city of Hradec Kralove where the conference Hradec Economic Days is held. The first cache in the Czech Republic was hidden already one year after the start of the game in June 2001. Within last two years, about 20,000 new caches have been placed in the Czech Republic. [12] The first cache in India was placed in January 2008 and six more caches were located within the same year. [2] The table 2 shows comparison of caches occurrence in Hradec Kralove, Prague and New Delhi.

Table 2. Geocaching in Hradec Králové and in New Delhi [2]

\begin{tabular}{lcccc}
\hline & $\begin{array}{c}\text { Hradec Králové }- \\
16 \mathrm{~km} \text { radius }\end{array}$ & $\begin{array}{c}\text { Hradec Králové } \\
5 \mathrm{~km} \text { radius }\end{array}$ & $\begin{array}{c}\text { Prague }-16 \\
\text { km radius }\end{array}$ & $\begin{array}{c}\text { New Delhi }- \\
16 \text { km radius }\end{array}$ \\
\hline Traditional & 351 & 134 & 1153 & 12 \\
Multi-cache & 119 & 39 & 457 & 1 \\
Mystery & 252 & 120 & 1203 & 0 \\
EarthCache & 1 & 0 & 75 & 2 \\
Letterbox Hybrid & 6 & 4 & 46 & 0 \\
Event & 4 & 2 & 40 & 0 \\
Webcam & 0 & 0 & 59 & 0 \\
Wherigo & 3 & 2 & 1 & 0 \\
Virtual & 0 & 0 & 8 & 0 \\
& 736 & 301 & 3068 & 15 \\
\hline
\end{tabular}

The occurrence of caches is visualised also by means of maps. Fig. 1 and fig. 2 show the occurrence and kinds of caches in Hradec Kralove and New Delhi.

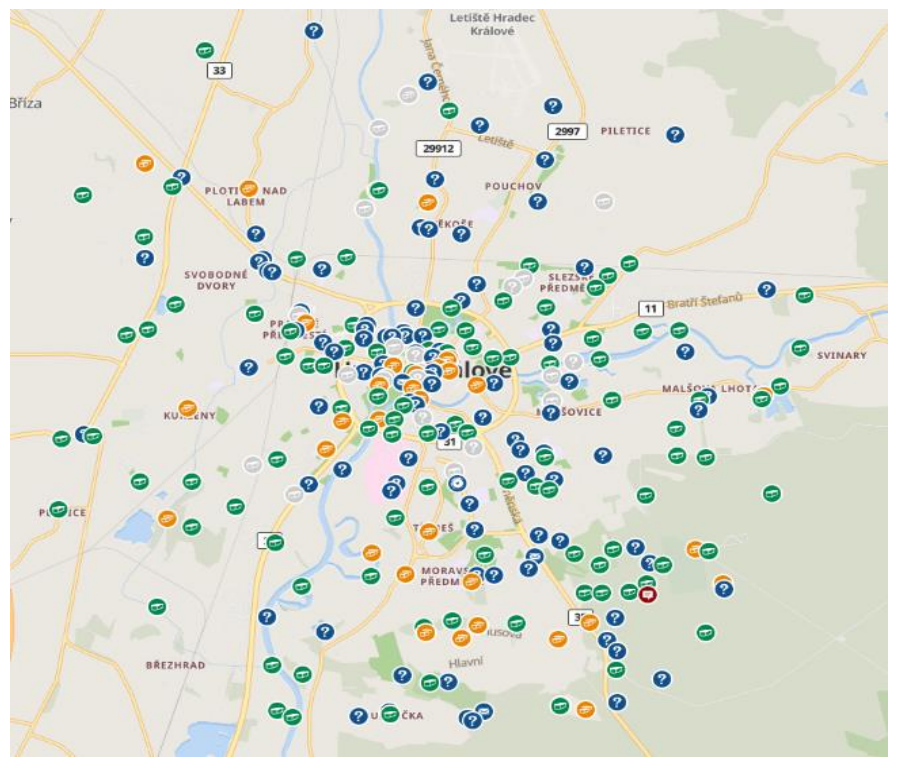

Fig. 1. Geocaches in Hradec Králové, radius 5 km [2] 
Various kinds of caches typical for the game are listed and compared in the table 2 and figures 1 and 2. New Delhi is nearly four times larger, that is why two size categories were applied when describing amount of caches in Hradec Kralove: the large and smaller radius. Traditional caches dominate in both cities but with enormous difference in occurrence. These traditional caches are in Hradec Králové followed by Mystery and Multi-caches also in high numbers. As for New Delhi there is only one occurrence of Multi-cache and two EarthCaches. Prague has been a significant tourist destination. The Czech Republic is favorite tourist and cultural destination boasting with number of historical sights and caches which are visited and found. Geocaching is popular with Czech people and a lot of people are engaged into this trendy "sport". As for India structured surveys were distributed to the sample of people at University. In spite of the fact that those are the people that are competent in technologies they are not familiar with geocaching. Because of the fact that they do not know this tech game, they do not create new caches and do not administrate and search for them. On the other side the Czech people are very active in all roles of this topic.

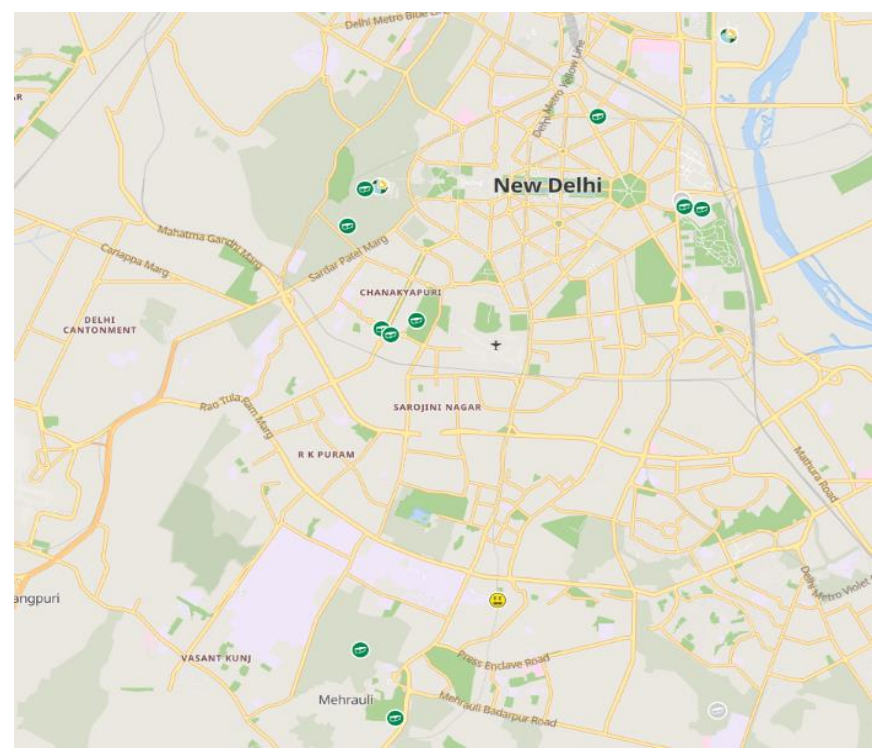

Fig. 2. Geocaches in New Delhi, radius $16 \mathrm{~km}[2]$

Another vital reason of minimal spread of caches in India might be literacy of citizens and utilization of technologies including internet accessibility. That is why we have focused on findings relevant data containing current actual situation in network readiness index in both countries. Next part discusses selected aspects dealing with literacy and technological issues utilized in geocaching support. 


\subsection{Network readiness index in the Czech Republic and in the India}

The other part of findings relates to the comparison of the CR and India based on the Network Readiness Index (NRI). "NRI measures the capacity of countries to use ICTs for increased competitiveness and well-being. It is now emerged as a key indicator of how countries are doing in the digital world. The significance of NRI is that several basic infrastructure facilities, policy frameworks etc., are to be built to achieve the benefit of digital revolution. The NRI measures the level of preparedness of countries on this." [10]

Altogether, there were 139 countries involved into the assessment. Network Readiness Index is a composite indicator that is rather complex; it consists of four main categories, ten pillars and 51 individual indicators. The names of pillars follow: 1st pillar: Political and regulatory environment, 2nd pillar: Business and innovation environment, 3rd pillar: Infrastructure and digital content, 4th pillar: Affordability, 5th pillar: Skills, 6th pillar: Individual usage 7th pillar: Business usage 8th pillar: Government usage 9th pillar: Economic impacts and 10th pillar: Social impacts. Individual indicators are assessed on the scale 1-7 (best).

Out of individual indicators, the following ones are found important for Geocaching: Mobile network coverage \% pop., International Internet bandwidth $\mathrm{kb} / \mathrm{s} / \mathrm{user}$, Secure Internet servers /million pop., Mobile cellular tariffs PPP \$/minute, Fixed broadband Internet tariffs PPP $\$$ /month, Internet and telephony sectors competition index, Adult literacy rate \%, Mobile-cellular telephone subscriptions /100 pop., Internet users $\%$ pop., Households with a personal computer \%, Households with Internet access \%, Fixed-broadband Internet subscriptions /100 pop., Mobilebroadband subscriptions /100 pop., Use of virtual social network, Impact of ICTs on new services and products, Impact of ICTs on access to basic services and Internet access in schools.

The table 3 shows results from two compared countries on the basis of the Network Readiness Index.

Table 3. Network readiness index in the Czech Republic and in India [14, 15]

\begin{tabular}{lcc}
\hline & Czech Republic & India \\
\hline Environment subindex & 40 & 99 \\
Political and regulatory environment (9 indicators) & 35 & 78 \\
Business and innovation environment (9 indicators) & 47 & 110 \\
Readiness subindex & 22 & 88 \\
Infrastructure (4 indicators) & 23 & 114 \\
Affordability (3 indicators) & 46 & 8 \\
Skills (4 indicators) & 39 & 101 \\
Usage subindex & 37 & 103 \\
Individual usage (7 indicators) & 29 & 120 \\
Business usage (6 indicators) & 31 & 75 \\
Government usage (3 indicators) & 101 & 59 \\
Impact subindex & 43 & 73 \\
Economic impacts (4 indicators) & 32 & 80 \\
\hline
\end{tabular}


The Czech Republic reaches better results in most of indicators except for:

- mobile cellular tariffs,

- fixed broadband internet tariffs

- and internet and telephony sectors competition index.

\section{Conclusion and implications for the discussion}

The goal and sub-goals were reached as they were described in the chapter Findings. The important findings relate to The Network Readiness Index; India is better compared to the Czech Republic with only two indicators of affordability and government use, which was the worst indicator for the Czech Republic. The rating of affordability is not very surprising. Includes, in particular, PPP \$ / minute Mobile Cellular Tariffs, PPP \$ / month Fixed Broadband Internet Tariffs and Internet and Telephony Sector Competition Index. While in India these services are at a lower price level, this is not the case in the Czech Republic. In terms of government usage, it evaluates the importance of ICTs to the government's vision of the future, the Government Online Service Index and Government's success in ICT promotion. For all three ratings, it is rated according to the subjective opinion from 1 to 7 (7 best). Here, perceptions and assessments of different nationalities can occur. While India seeks to highlight government usage in the Czech Republic it is not that case.

When it comes to economic benefits arising from Geocaching, is necessary to mention that tourism revenue is brought to the cultural sites via the adventure of the exploration of local or historical attractions and via development of businesses. On the official Geocaching website there is a section with a turnkey marketing program called 'A GeoTour' sophistically combining Geocaching and Tourism. 'A GeoTour' is a customized package pointing travel-ready players to their destination. Destination becomes a target for their game, enjoyed by locals and visitors alike. With measurable data, it is possible to monitor the return on the investment. "It's more than just techy fun; it's a measurable investment in your destination. This is how your destination enters the arena of mobile experiential gaming". [22] Amount of caches is a distinctive indicator of Geocaching popularity in individual countries. Geocaching is a promising tool which is being used in the promotion of the Cultural heritage. This paper strives to contribute to the exploration of Geocaching potential.

Following analyzed area might be measuring of visits and founds of caches. At first sight it can be seen that caches in the Czech Republic are more frequently visited and newly founded and carefully administrated. [2] Another interesting and fruitful perspective might be gained from the economic benefit for the destination in the connection with sustainability tourism.

Acknowledgements. This study is supported by internal research project No. 2103/2017 Investment under concept Industry 4.0 at Faculty of Informatics and 
Management, University of Hradec Kralove, Czech Republic. We would like to thank student Martin Král for cooperation in the processing of the article.

\section{References}

1. Craighead, J: Promoting Cultural Heritage without much cash in the cache: A case for Geocaching. In: AMCIS 2009 proceedings, p. 1732. San Francisco (2009).

2. Geocaching, www.geocaching.com, last accessed 2017/11/10

3. Google Scholar, https://scholar.google.cz/, last accessed 2017/11/10

4. Healy K.: The Performativity of Networks. European Journal of Sociology 56(2), 175-205 (2015), DOI:10.1017/S0003975615000107

5. Hoppe, C.J., Rettberg, J.W.: Experiences with geographical collaborative systems: playfulness in geosocial networks and geocaching, eprints.soton.ac.uk, last accessed 2017/11/10

6. Hödl, C., Pröbstl-Haider, U.: Geocaching in Austrian National Parks. Eco Mont-journal on protected mountain areas research. 9(2), $42-51$ (2017), DOI: 10.1553/eco.mont-9-2s42

7. Ihamäki, P.: The Potential of Treasure Hunt Games to Generate Positive Emotions in Learners: Experiencing Local Geography and History using GPS Devices. International Journal of Technology Enhanced Learning 6(1), 5-20 (2014), DOI: 10.1504/IJTEL.2014.060025

8. Ihamäki, P.: Design the Pori Hidden Beauties Geocaching Series: Computer-Supported Collaborative Web-Based Learning and Sharing Experiences. International Journal of Web Based Communities 11(2), pp. 131-152 (2015), DOI: 10.1504/IJWBC.2015.068538

9. Ihamäki, P.: User Experience of Geocaching and Its Application to Tourism and Education, Phd thesis, Annales Universitatis Turkuensis B404, University of Turku, Juvenes, https://www.doria.fi/handle/10024/105143, last accessed 2017/11/10

10. IndianEconomy.net. What is Networked Readiness Index? http://www.indianeconomy.net/splclassroom/337/what-is-networked-readiness-index/, last accessed 2017/11/10

11. International Monetary Fund (IMF). World Economic Outlook Database, April 2017 Report for Selected Countries and Subjects, https://www.imf.org/external/pubs/ft/weo/2017/01/weodata/index.aspx, last accessed 2017/11/10

12. Kronika českého geocachingu. http://wiki.geocaching.cz/wiki/Kronika_\%C4\%8Desk\%C3\%A9ho_geocachingu, last accessed 2017/11/10

13. MacKenzie, D., Muniesa, F. and Siu, L.: Do Economists Make Markets? On the Performativity of Economics. Princeton University Press, New Jersey (2007)

14. Network Readiness Index. India, http://reports.weforum.org/global-informationtechnology-report-2016/economies/\#economy=IND, last accessed 2017/11/10

15. Network Readiness Index. Czech Republic, http://reports.weforum.org/global-informationtechnology-report-2016/economies/\#economy=CZE, last accessed 2017/11/10

16. Remeš, R., Vítek, O.: Czechia - The geocaching power. In: Recreation and Nature Conservation 2010, pp. 5-7, Mendelova univerzita v Brně, Křtiny (2010).

17. Scaraboto, D.: Selling, sharing, and everything in between: The hybrid economies of collaborative networks. Journal of Consumer Research 42(1), 152-176 (2015), DOI: $10.1093 / \mathrm{jcr} / \mathrm{ucv004}$

18. Science Direct, www.sciencedirect.com, last accessed 2017/11/10 
19. Springer, www.springer.com, last accessed 2017/11/10

20. Scopus, www.scopus.com, last accessed 2017/11/10

21. States Parties - UNESCO World Heritage Centre. http://whc.unesco.org/en/statesparties/, last accessed 2017/11/10

22. Travel with GeoTours, https://www.geocaching.com/travel/ last accessed 2017/11/10

23. UNESCO Czech heritage: Twelve Czech wonders of the world. http://en.czechunesco.org/, last accessed 2017/11/10

24. Webb, R. M.: Recreational Geocaching: The Southeast Queensland Experience. In: 2001 A Spatial Odyssey- Australian Surveying Congress - Brisbane September 2001, Brisbane Convention Centre, https://eprints.qut.edu.au/4160/, last accessed 2017/11/10

25. Web of Science, www.webofscience.com, last accessed 2017/11/10 